\title{
PTEN/AKT/mTOR signaling mediates anticancer effects of epigallocatechin-3-gallate in ovarian cancer
}

\author{
JIANLI QIN $^{1 *}$, MINGLEI FU $^{2 *}$, JUAN WANG $^{3}$, FENGXIANG HUANG $^{1}$, HAIPING LIU ${ }^{4}$, \\ MENGJIE HUANGFU ${ }^{1}$, DAN YU ${ }^{1}$, HAOWEI LIU ${ }^{1}$, XUMEI LI ${ }^{1}$, XIAO GUAN ${ }^{1,5}$ and XU CHEN ${ }^{1}$ \\ ${ }^{1}$ College of Pharmacy, Guilin Medical University; ${ }^{2}$ Dispensary, The Second Affiliated Hospital of Guilin Medical University; \\ ${ }^{3}$ Research Center for Science; ${ }^{4}$ Science and Technology Department, Guilin Medical University, Guilin, Guangxi 541004; \\ ${ }^{5}$ Xiangya Hospital, Central South University, Changsha, Hunan 410008, P.R. China
}

Received October 8, 2019; Accepted March 12, 2020

DOI: $10.3892 /$ or.2020.7571

\begin{abstract}
Epigallocatechin-3-gallate (EGCG), a polyphenol present in green tea, exhibits anticancer effects in various types of cancer. A number of studies have focused on the effects of EGCG on lung cancer, but not ovarian cancer. Previous reports have implicated that EGCG suppressed ovarian cancer cell proliferation and induced apoptosis, but its potential anticancer mechanisms and signaling pathways remain unclear. Thus, it is necessary to determine the anti-ovarian cancer effects of EGCG and explore the underlying mechanisms. In the present study, EGCG exerted stronger proliferation inhibition on SKOV3 cells compared with A549 cells and induced apoptosis in SKOV3 cells, as well as upregulated PTEN expression and downregulated the expression of phosphoinositide-dependent kinase-1 (PDK1), phosphor (p)-AKT and p-mTOR. These effects were reversed by the PTEN inhibitor VO-Ohpic trihydrate. The results of the mouse xenograft experiment demonstrated that $50 \mathrm{mg} / \mathrm{kg}$ EGCG exhibited increased tumor growth inhibition compared with $5 \mathrm{mg} / \mathrm{kg}$ paclitaxel. In addition, PTEN expression was upregulated, whereas the expression levels of PDK1, p-AKT and p-mTOR were downregulated in the EGCG treatment group compared with those in untreated mice in vivo. In conclusion, the results of the present study provided a new underlying mechanism of the effect of EGCG on ovarian cancer and may lead to the development of EGCG as a candidate drug for ovarian cancer therapy.
\end{abstract}

Correspondence to: Professor $\mathrm{Xu}$ Chen, College of Pharmacy, Guilin Medical University, 109 North Second Ring Road, Qixing, Guilin, Guangxi 541004, P.R. China

E-mail: chenxu@glmc.edu.cn

${ }^{*}$ Contributed equally

Key words: epigallocatechin-3-gallate, ovarian cancer, proliferation, apoptosis, VO-Ohpic trihydrate

\section{Introduction}

Epigallocatechin-3-gallate (EGCG) is isolated from green tea, which originated in China, and belongs to a class of catechuic monomers (1). Numerous studies have reported that EGCG exhibits anticancer activity against various types of cancer, including cervical, prostate, breast, colorectal, esophageal and lung cancer (2-7). EGCG exerts its anticancer activity by suppressing cell proliferation, migration and invasion, and by inducing apoptosis in lung cancer cells (8-11). A number of studies on the anticancer activity of EGCG focus on lung cancer cells $(12-16)$; however, few studies $(17,18)$ focus on ovarian cancer cells.

Ovarian cancer is a prevalent gynecological malignancy, which severely threatens women's health (19). Ovarian cancer occurs in women with a prevalence $\sim 15,000$ per 100,000 individuals worldwide (20). Due to a lack of specific symptoms in the early stages, $60-70 \%$ of patients with ovarian cancer are diagnosed at an advanced stage, and their 5-year survival rate is $\sim 40 \%(21,22)$. Standard therapy strategies for advanced-stage ovarian cancer are primary debulking surgery combined with platinum and paclitaxel chemotherapy $(23,24)$. Although chemotherapy can increase the median survival of ovarian cancer, the toxicity and drug resistance causes the failure of chemotherapy and recurrence of the tumor (25-27). Thus, new drugs with low toxicity and high efficacy to treat ovarian cancer are urgently required.

The PTEN/AKT/mTOR pathway is involved in the progression of ovarian cancer and is activated in $<70 \%$ of ovarian cancer cases, which makes this pathway crucial in ovarian cancer therapy $(28,29)$. A previous bioinformatics analysis has highlighted the potential use of EGCG in ovarian cancer treatment (30), but these findings lacked experiment data support. Thus, the aim of the present study was to investigate the molecular mechanism of EGCG as well as its anticancer activity in SKOV3 cells and a xenograft model, and to support clinical application of EGCG in the treatment of ovarian cancer.

\section{Materials and methods}

Cell culture and treatment. Ovarian cancer cell lines SKOV3, CAOV-3 and NIH-OVCAR-3 were obtained from 
the Kunming Cell Bank, Conservation Genetics, the Chinese Academy of Sciences. EGCG was purchased from Dalian Meilun Biotechnology Co., Ltd. The lung cancer cell line A549 and human retinal pigment epithelium (RPE) cell line were obtained from the Shanghai Cell Resource Center, the Chinese Academy of Biological Sciences. SKOV3 cells were maintained in RPMI-1640 medium (Gibco; Thermo Fisher Scientific, Inc.), whereas the other cell lines were maintained in DMEM medium supplemented with $10 \%$ fetal bovine serum (both Invitrogen; Thermo Fisher Scientific, Inc.) and 1\% antibiotic solution $(100 \mathrm{U} / \mathrm{ml}$ penicillin and $100 \mu \mathrm{g} / \mathrm{ml}$ streptomycin) under humidified conditions with $5 \% \mathrm{CO}_{2}$ at $37^{\circ} \mathrm{C}$. EGCG was dissolved to different concentrations $(0,5,10$, 20, 40 and $80 \mu \mathrm{g} / \mathrm{ml}$ ) in RPMI-1640 medium; VO-Ohpic trihydrate (VO-Ohpic; Sigma-Aldrich; Merck KGaA) was dissolved in DMSO (Xilong Chemical Industry, China) and diluted to $0.1 \mu \mathrm{M}$ with RPMI-1640 medium.

Cell viability assay. The viability of SKOV3, A549, CAOV-3 and NIH-OVCAR-3 cells was measured by MTT assay. First, a total of $3 \times 10^{3}$ cells were seeded in 96 -well plates and treated with different concentrations of EGCG $(0,5,10$, 20,40 and $80 \mu \mathrm{g} / \mathrm{ml}$ ) for $24,48,72 \mathrm{~h}$ at $37^{\circ} \mathrm{C}$. Subsequently, $20 \mu \mathrm{l} \mathrm{MTT}$ solution $(5 \mathrm{mg} / \mathrm{ml})$ was added to the cells and incubated for another $4 \mathrm{~h}$ at $37^{\circ} \mathrm{C}$. Finally, $150 \mu \mathrm{l}$ DMSO was used to dissolve the formazan complex, and the optical density was measured at $490 \mathrm{~nm}$ using a microplate reader (Tecan Group, Ltd.).

Cell colony forming assay. SKOV3 cells $\left(5 \times 10^{2}\right)$ were seeded into 6-well plates. Following treatment with different concentrations of EGCG $(0,5,10,20,40 \mu \mathrm{g} / \mathrm{ml})$, the cells were cultured for another 10-12 days at $37^{\circ} \mathrm{C}$ with $5 \% \mathrm{CO}_{2}$. Subsequently, the colonies were fixed with absolute methyl alcohol at $25^{\circ} \mathrm{C}$ for $20 \mathrm{~min}$ and stained with Giemsa solution at $25^{\circ} \mathrm{C}$ for $30 \mathrm{~min}$. Finally, the number of colonies containing $>50$ cells were counted under a light microscope.

Apoptosis analysis by flow cytometry. Following EGCG treatment for $48 \mathrm{~h}$ at $37^{\circ} \mathrm{C}$, SKOV3 cells were collected, washed twice with ice-cold PBS and suspended in $100 \mu \mathrm{l} 1 \mathrm{X}$ binding buffer (BD Biosciences). The cells were stained using an Annexin V-FITC apoptosis detection kit (BD Biosciences) by incubation with $5 \mu \mathrm{l}$ Annexin V-FITC and propidium iodide for $30 \mathrm{~min}$ in the dark, followed by the addition of another $100 \mu 11 \mathrm{X}$ binding buffer and filtration with 300 mesh. Early and late apoptosis was determined using BD Accuri C6 Plus flow cytometer (BD Biosciences), and the results were analyzed by FlowJo-V10 software (FlowJo LLC).

Reverse transcription-quantitative PCR (RT-qPCR). Following EGCG treatment for $48 \mathrm{~h}$ at $37^{\circ} \mathrm{C}$, total RNA was extracted from SKOV3 cells using TRIzol ${ }^{\circledR}$ reagent (Tiangen Biotech Co., Ltd.) and reverse-transcribed into cDNA using a GoScript $^{\mathrm{TM}}$ Reverse Transcription Mix (Promega, Biotech Co., Ltd, Beijing) at $42^{\circ} \mathrm{C}$ for $20 \mathrm{~min}$ and $90^{\circ} \mathrm{C}$ for $5 \mathrm{~min}$. QPCR analysis was performed using UltraSYBR Mixture (CW Bio) on the ABI 7500 Fast Real-Time PCR Detection system (Thermo Fisher Scientific, Inc.). The thermocycling conditions for were as follows: $95^{\circ} \mathrm{C}$ for $30 \mathrm{sec}, 40$ cycles
Table I. Sequences of forward and reverse primers used in reverse transcription-quantitative PCR.

\begin{tabular}{ll}
\hline Gene & \multicolumn{1}{c}{ Sequences $\left(5^{\prime} \rightarrow 3^{\prime}\right)$} \\
\hline Bcl-2 & F: GCCACTTACCTGAATGACCACC \\
& R: AACCAGCGGTTGAAGCGTTCCT \\
Bax & F: AGACACCTGAGCTGACCTTGGAG \\
& R: GTTGAAGTTGCCATCAGCAAACA \\
Caspase-3 & F: AGAACTGGACTGTGGCATTGAG \\
& R: GCTTGTCGGCATACTGTTCAG \\
AKT & F: AGAACCTCATRCTGGACAA \\
& R: CTCATGGTCCTGGTTGTAGA \\
PTEN & F: CAGTAGAGGAGCCGTCAAATC \\
& R: CAGAGTCAGTGGTGTCAGAATATC \\
mTOR & F: TCCGAGAGATGAGTCAAGAGG \\
& R: CACCTTCCACTCCTATGAGGC \\
& F: AAAGACCTGTACGCCAACAC \\
& R: GTCATACTCCTGCTTGCTGAT
\end{tabular}

of $95^{\circ} \mathrm{C}$ for $5 \mathrm{sec}$ and $60^{\circ} \mathrm{C}$ for $30 \mathrm{sec}$, followed by $95^{\circ} \mathrm{C}$ for $15 \mathrm{sec}, 60^{\circ} \mathrm{C}$ for $1 \mathrm{~min}, 95^{\circ} \mathrm{C}$ for $15 \mathrm{sec}$ and $50^{\circ} \mathrm{C}$ for $30 \mathrm{sec}$. The primer sequences used in this study are presented in Table I. The relative mRNA expression levels were analyzed using the $2^{-\Delta \Delta \mathrm{Cq}}$ method (31).

Western blot assay. Following treatment with EGCG for $48 \mathrm{~h}$ at $37^{\circ} \mathrm{C}$, cells were lysed in RIPA buffer with $2 \mu \mathrm{g} / \mathrm{ml}$ aprotinin, $5 \mu \mathrm{g} / \mathrm{ml}$ leupeptin, $1 \mu \mathrm{g} / \mathrm{ml}$ pepstatin, $15 \mathrm{mM}$ DTT and $1 \mathrm{mM}$ PMSF. The lysates were centrifuged at 9,180 x g for $25 \mathrm{~min}$ at $4^{\circ} \mathrm{C}$. The protein concentrations were measured using a Bicinchoninic Acid (BCA) Protein Quantitation kit (Beyotime Institute of Biotechnology). The protein samples $(30 \mu \mathrm{g} /$ lane $)$ were isolated by 8 or $10 \%$ SDS-PAGE and electro-transferred to nitrocellulose membranes. The membranes were blocked with $5 \%(\mathrm{w} / \mathrm{v})$ skimmed milk in PBS $+0.1 \%$ Tween-20 (PBST) for $2 \mathrm{~h}$, followed by incubation with primary antibodies against Bax (cat. no. ab182733; 1:2,000; Abcam), Bcl-2 (cat. no. ab182858; 1:2,000; Abcam), total caspase-3 (cat. no. ab32351; 1:2,000; Abcam), PTEN (cat. no. ab32199; 1:2,000; Abcam), phosphoinositide-dependent kinase-1 (cat. no. WL00707; PDK1; 1:1,000; Wanleibio Co., Ltd.), AKT (cat. no. ab18785; 1:2,000; Abcam), phosphor (p)-AKT (cat. no. WLP001a; Ser473; 1:1,000; Wanleibio Co., Ltd.), mTOR (cat. no. ab32028; 1:2,000; Abcam), p-mTOR (cat. no. ab137133; 1:2,000; Abcam) and $\beta$-actin (cat. no. TA-09; 1:500; Beijing Zhongshan Golden Bridge Biotechnology Co., Ltd.) diluted in primary antibody diluent (Beyotime Biotechnology) overnight at $4^{\circ} \mathrm{C}$. The membranes were washed for $7 \mathrm{~min}$ with PBST three times and incubated with horseradish peroxidase-conjugated goat anti-rabbit or anti-mouse IgG secondary antibodies (cat. nos. 31430 and 31460; 1:5,000; Thermo Fisher Scientific, Inc.) for $1 \mathrm{~h}$ at $25^{\circ} \mathrm{C}$. Finally, the protein signals were detected using an X-ray film. The optical density of the protein bands was measured using ImageJ V1.8.0 software (National Institutes of Health). 
Table II. $\mathrm{IC}_{50}$ of epigallocatechin-3-gallate in four cancer cell lines.

\begin{tabular}{lrrr}
\hline & \multicolumn{3}{c}{$\mathrm{IC}_{50}, \mu \mathrm{g} / \mathrm{ml}$} \\
\cline { 2 - 4 } Cell line & \multicolumn{1}{c}{$24 \mathrm{~h}$} & $48 \mathrm{~h}$ & $72 \mathrm{~h}$ \\
\hline SKOV3 & 34.58 & 26.07 & 22.04 \\
NIH-OVCAR-3 & 349.62 & 118.82 & 82.19 \\
CAOV-3 & 410.81 & 123.67 & 57.64 \\
A549 & 72.61 & 56.67 & 29.24 \\
\hline
\end{tabular}

A

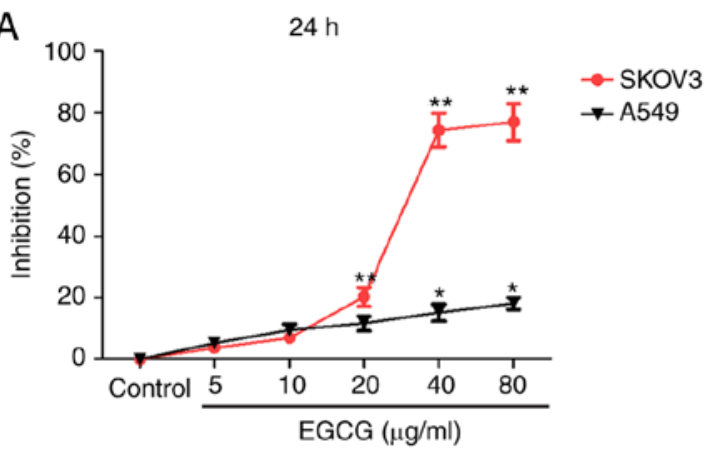

C

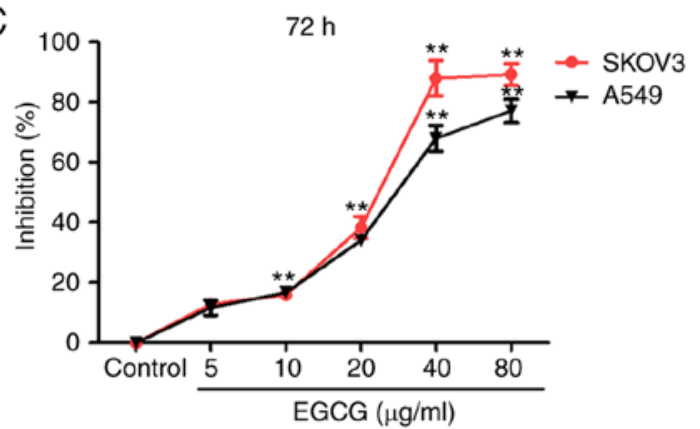

E

E CAOV-3

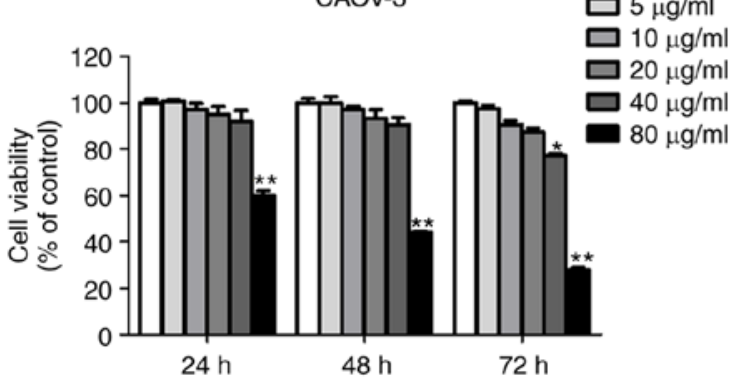

G

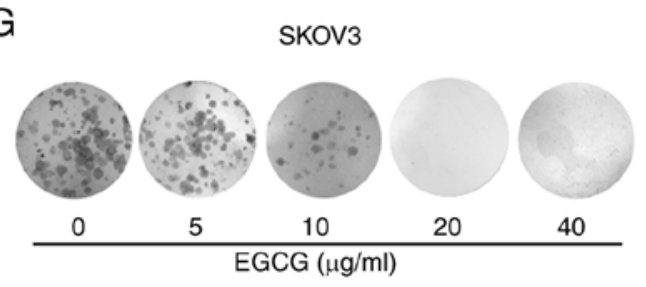

B
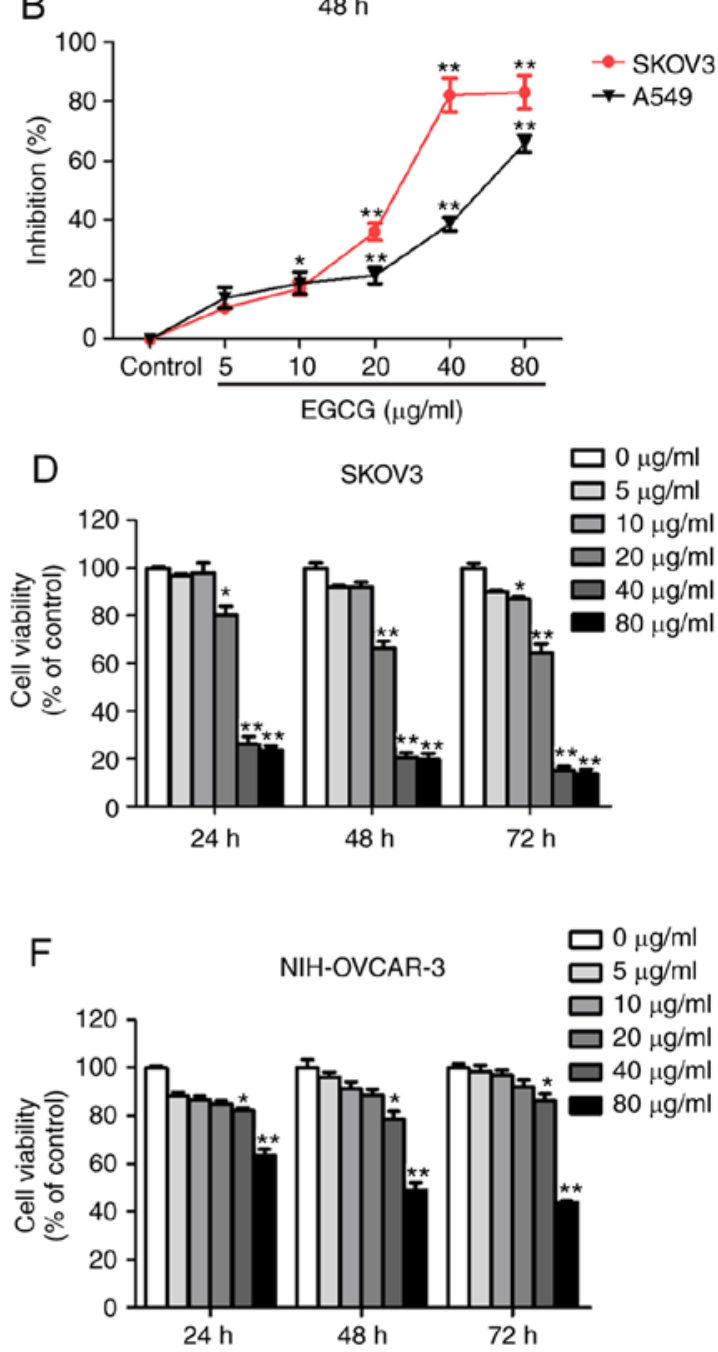

$\mathrm{H}$

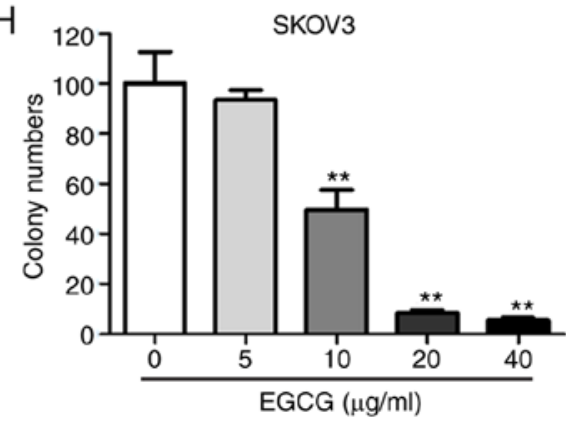

Figure 1. EGCG inhibits ovarian cancer cell proliferation. Inhibitory effects of EGCG on SKOV3 and A549 cells were evaluated by MTT assay at (A) 24 , (B) 48 and (C) $72 \mathrm{~h}$. The viability of (D) SKOV3, (E) CAOV-3 and (F) NIH-OVCAR-3 cells was analyzed by MTT assay. (G and H) Cell colony forming ability was assessed by colony formation assay. $\mathrm{N}=3 .{ }^{*} \mathrm{P}<0.05,{ }^{* *} \mathrm{P}<0.01$ vs. control. EGCG, epigallocatechin-3-gallate. 

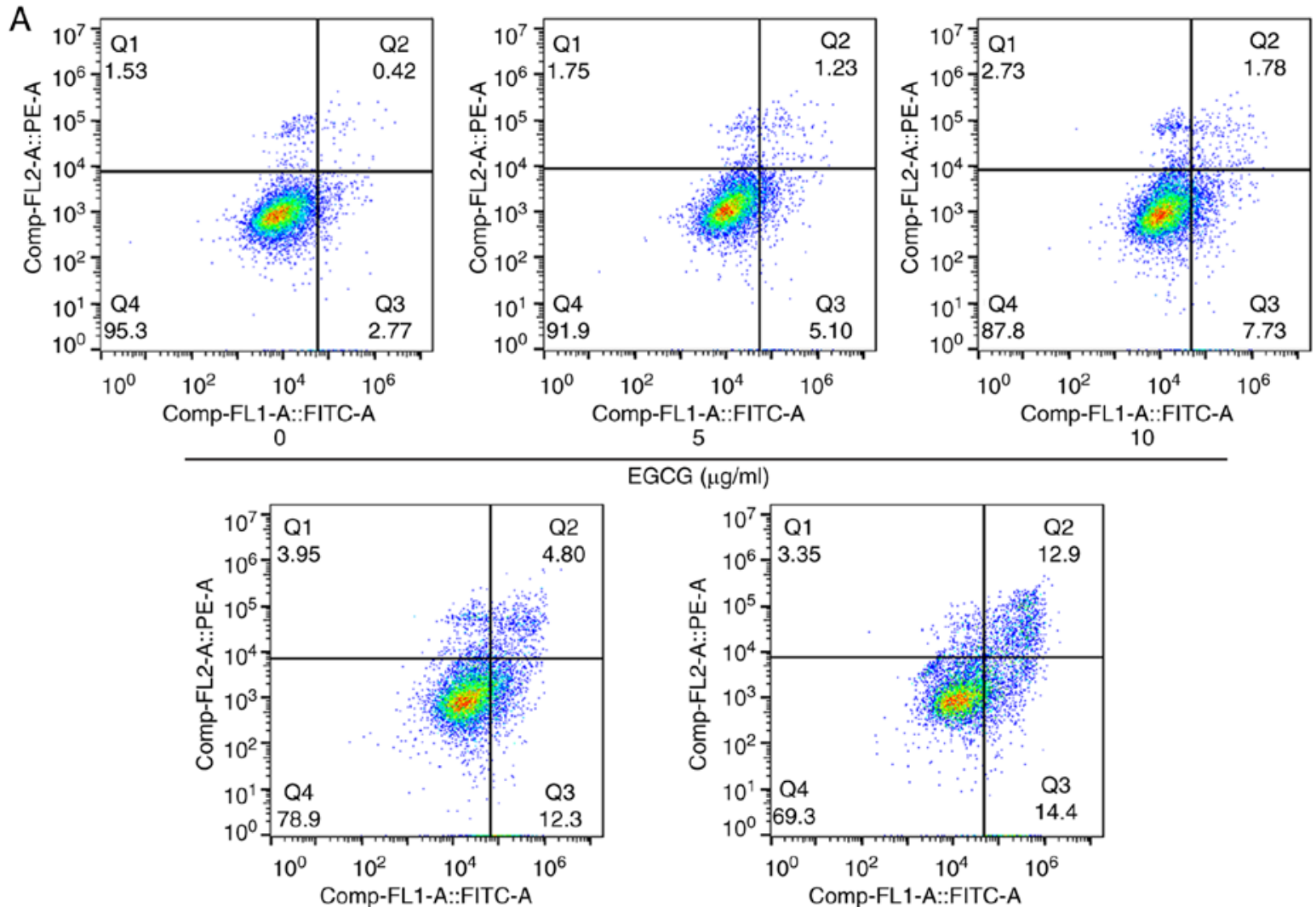

5

EGCG $(\mu \mathrm{g} / \mathrm{ml})$

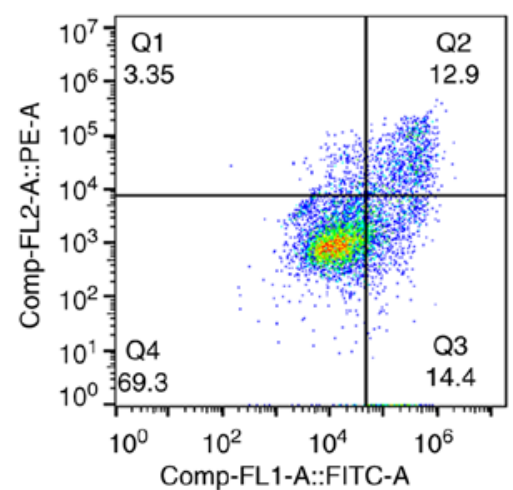

40

EGCG $(\mu \mathrm{g} / \mathrm{ml})$
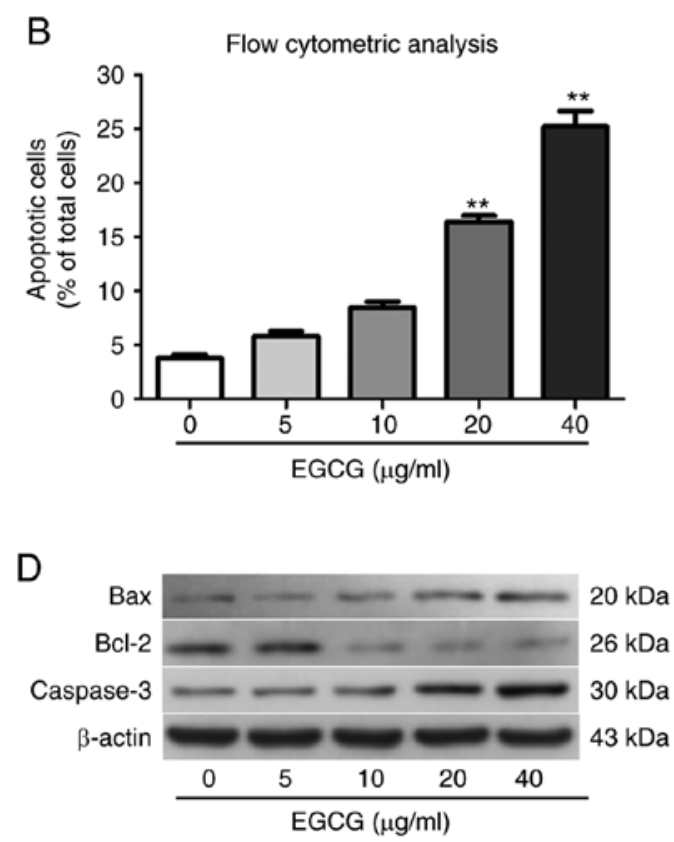
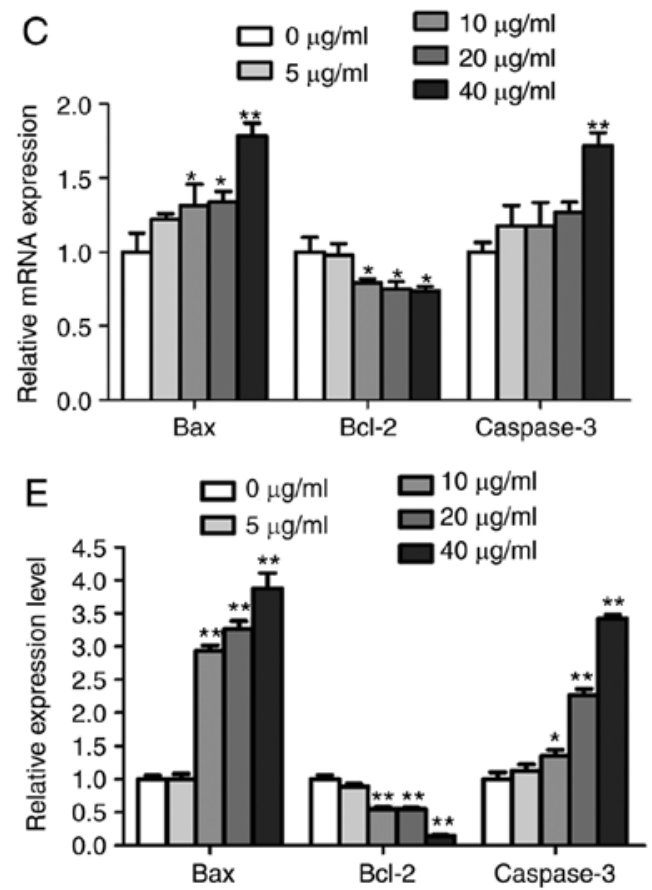

Figure 2. EGCG induces apoptosis in ovarian cancer SKOV3 cells. (A and B) Apoptosis was detected by flow cytometry following 48-h treatment with EGCG. (C) The mRNA expression levels of Bax, Bcl-2 and caspase-3 were detected by reverse transcription-quantitative PCR. (D and E) The protein expression of Bax, Bcl-2 and caspase- 3 were analyzed by western blotting. $\mathrm{N}=3$. ${ }^{*} \mathrm{P}<0.05,{ }^{* *} \mathrm{P}<0.01 \mathrm{vs} .0 \mu \mathrm{g} / \mathrm{ml}$. EGCG, epigallocatechin-3-gallate.

Ovarian cancer xenograft model. Female BALB/c nude mice (4-5 weeks old) were purchased from Hunan SJA Laboratory Animal Co., Ltd. A total of $1 \times 10^{7}$ SKOV3 cells in $200 \mu 1$ PBS were injected subcutaneously into the right flanks of the mice. Once the tumor volume reached $50 \mathrm{~mm}^{3}$, the animals were randomized into five groups ( $\mathrm{n}=7$ per group). The mice in the control group were administered normal saline; the positive control group were administered $5 \mathrm{mg} / \mathrm{kg}$ paclitaxel; 

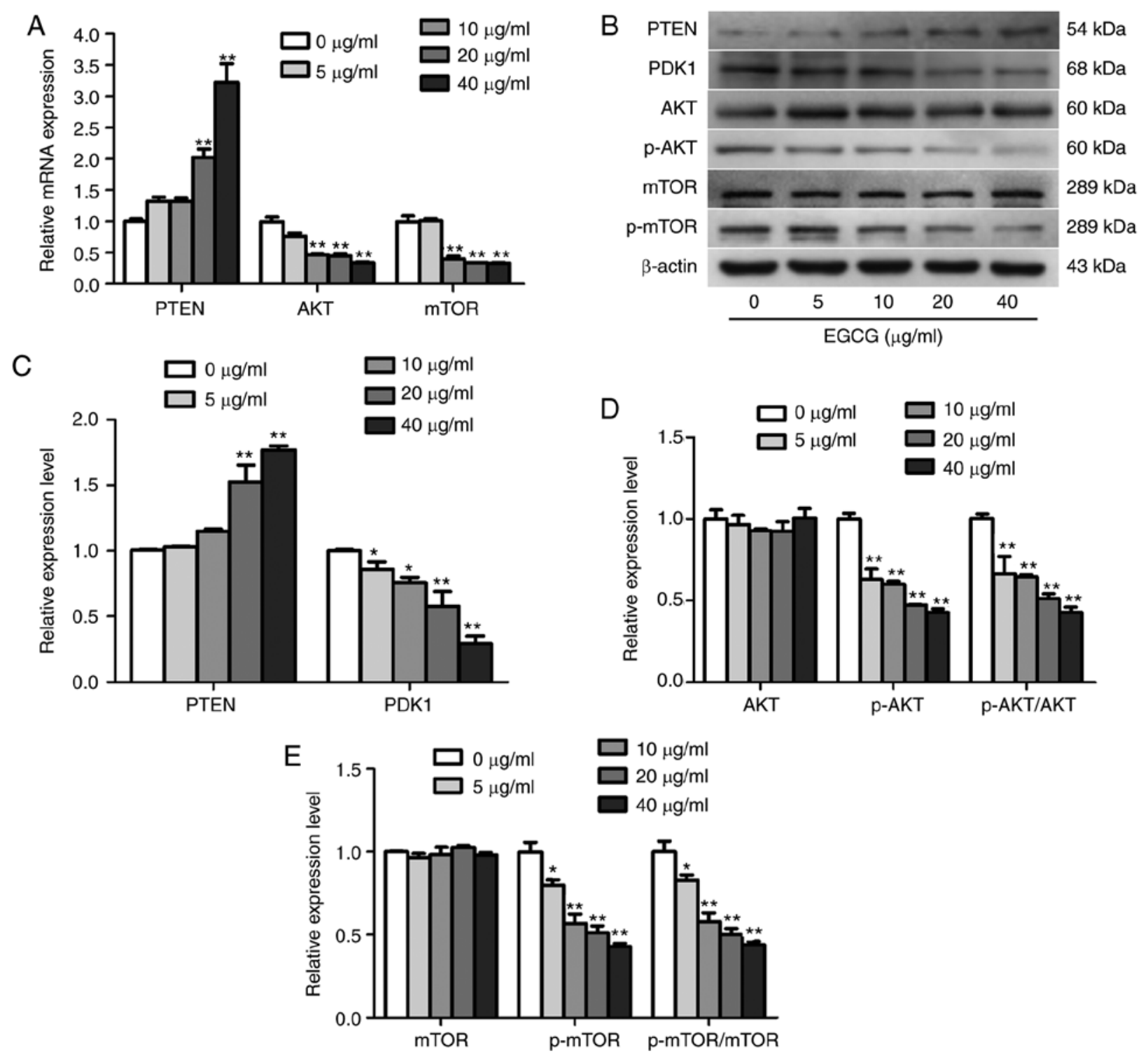

Figure 3. EGCG inhibits the PTEN/AKT/mTOR pathway activation in SKOV3 cells. (A) The mRNA expression of PTEN, AKT and mTOR were detected by reverse transcription-quantitative PCR. (B-E) The protein expression of (C) PTEN and PDK1, (D) AKT and p-AKT, and (E) mTOR and p-mTOR were analyzed by western blotting. The extent of phosphorylation of AKT and mTOR is presented as the ratio of p-AKT/AKT and p-mTOR/mTOR, respectively. $\mathrm{N}=3 .{ }^{*} \mathrm{P}<0.05,{ }^{* *} \mathrm{P}<0.01$ vs. $0 \mu \mathrm{g} / \mathrm{ml}$. EGCG, epigallocatechin-3-gallate; $\mathrm{p}$, phosphor.

and the mice in the experimental groups were administered 10,30 or $50 \mathrm{mg} / \mathrm{kg}$ EGCG. EGCG and saline were administered every day, and paclitaxel was administered twice a week. Tumor volume was calculated using the following formula: Volume=length $\mathrm{x}$ width ${ }^{2} / 2$. Following treatment for 21 days, the mice were euthanized, and tumor tissues were collected and maintained in a $-80^{\circ} \mathrm{C}$ deep freezer until further analysis. Ethical approval for the use of animals was obtained prior to the start of this study from the Institutional Animal Care and Use Committee of Guilin Medical University (Guilin, China), and all the animals used in the experiments were treated humanely.

Hematoxylin and eosin (HE) staining. Livers from nude mice were collected and immersed in a formaldehyde solution (37-40\% formaldehyde/PBS, $1: 9$ ) at $4{ }^{\circ} \mathrm{C}$ for $24 \mathrm{~h}$. After fixation, liver samples were dehydrated in 70, 80, 90 and $100 \%$ alcohol, cleared in pure benzene and embedded in paraffin. Then, $3-\mu \mathrm{m}$ sections were cut and mounted onto slides, followed by 10 -min dewaxing with fresh xylene for three times. Subsequently, the sections were placed in 100, 95, 85 and $75 \%$ alcohol for $5 \mathrm{~min}$ and stained with hematoxylin (Beijing Solarbio Science \& Technology Co., Ltd.) at $25^{\circ} \mathrm{C}$ for $15 \mathrm{~min}$. The sections were differentiated with hydrochloric alcohol, then dehydrated in $75,85,95$ and $100 \%$ alcohol for $5 \mathrm{~min}$. After dehydration, the sections were stained with eosin (Solarbio Biotechnology Company, Shanghai, China) at $25^{\circ} \mathrm{C}$ for $15 \mathrm{sec}$ and placed in fresh xylene for $5 \mathrm{~min}$. Finally, the sections were sealed with neutral gum. Morphological changes of liver tissue were observed under a light microscope.

Statistical analysis. The data are presented as the mean \pm SD of at least three independent experiments. All data were analyzed by SPSS version 17.0 (SPSS, Inc.), and one-way ANOVA followed by Tukey's post hoc test was used to assess 

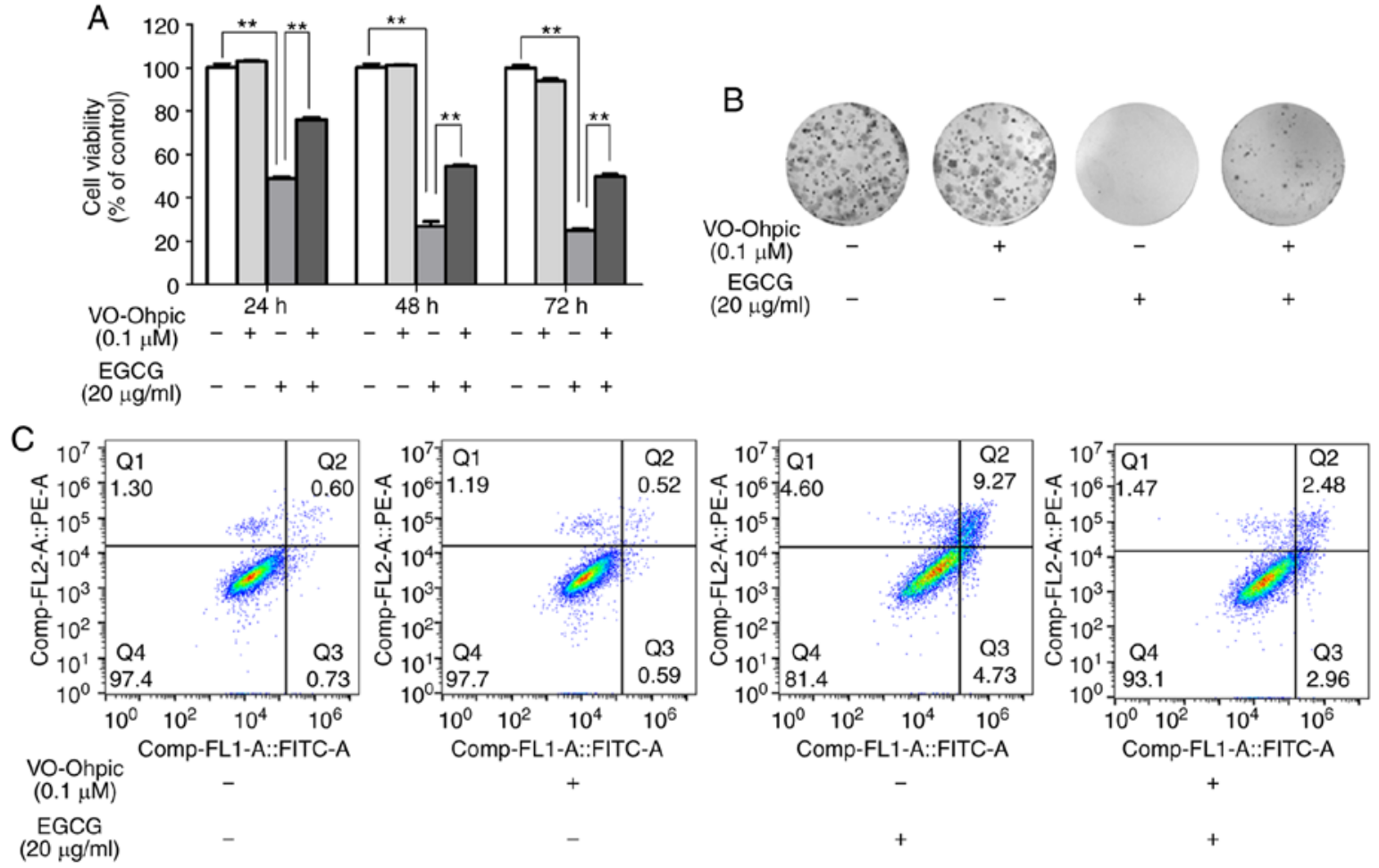

$$
(20 \mu \mathrm{g} / \mathrm{ml})
$$
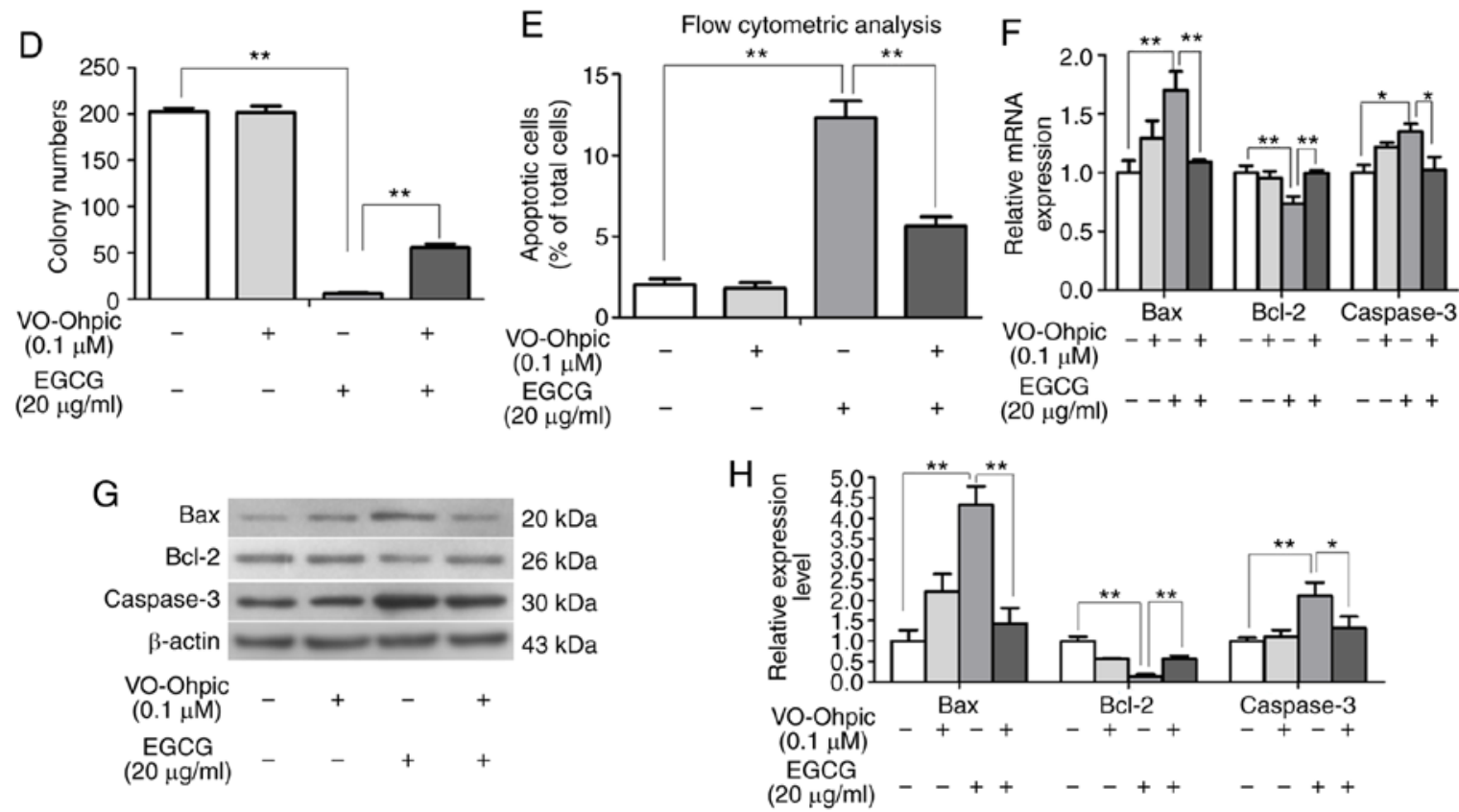

Figure 4. VO-Ohpic reverses the anticancer effect of EGCG in SKOV3 cells. (A) Cell viability was analyzed by MTT assay. (B and D) Cell colony forming ability was assessed by colony formation assay. (C and E) Apoptosis was detected by flow cytometry following 48-h treatment with EGCG and VO-Ohpic. (F) The mRNA expression levels of Bax, Bcl-2 and caspase-3 were detected by reverse transcription-quantitative PCR. (G and $\mathrm{H}$ ) The protein expression levels of Bax, Bcl-2 and caspase-3 were analyzed by western blotting. $\mathrm{N}=3 .{ }^{*} \mathrm{P}<0.05,{ }^{* *} \mathrm{P}<0.01$. EGCG, epigallocatechin-3-gallate.

the statistical significance. $\mathrm{P}<0.05$ was considered to indicate a statistically significant difference.

\section{Results}

EGCG inhibits cancer cell proliferation. To determine the EGCG-mediated proliferation inhibition in SKOV3 and A549 cells, cell viability was examined at 24, 48 and $72 \mathrm{~h}$ following treatment with a range of EGCG concentrations. As presented in Fig. 1A-C, EGCG exhibited a significant proliferation inhibition on SKOV3 cell and A549 cells. In addition, CAOV-3 and NIH-OVCAR-3 cell lines were used to investigate the EGCG-mediated proliferation inhibition. The results demonstrated that EGCG inhibited SKOV3, CAOV-3 and NIH-OVCAR-3 cell proliferation in a dose- and time-dependent manner (Fig. 1D-F). Among the four cell lines, SKOV3 exhibited the lowest $\mathrm{IC}_{50}$ values, suggesting that it was more sensitive to EGCG compared with the other three cell lines (Table II). In addition, to detect the toxicity of EGCG to normal cells, EGCG was used to treat normal human 
A

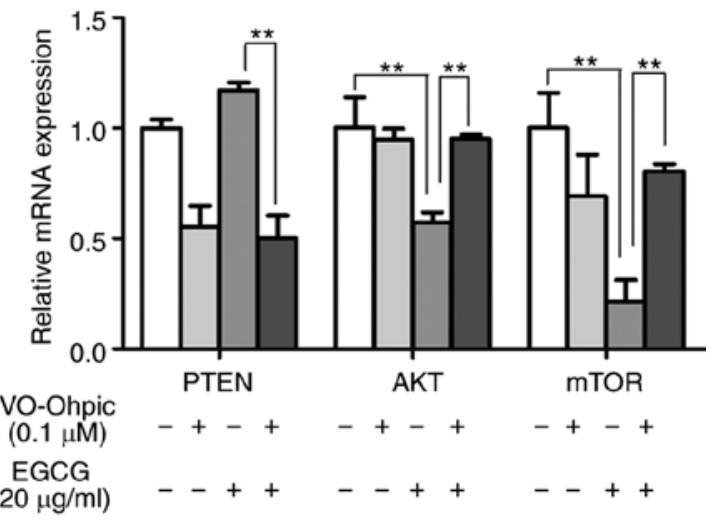

C

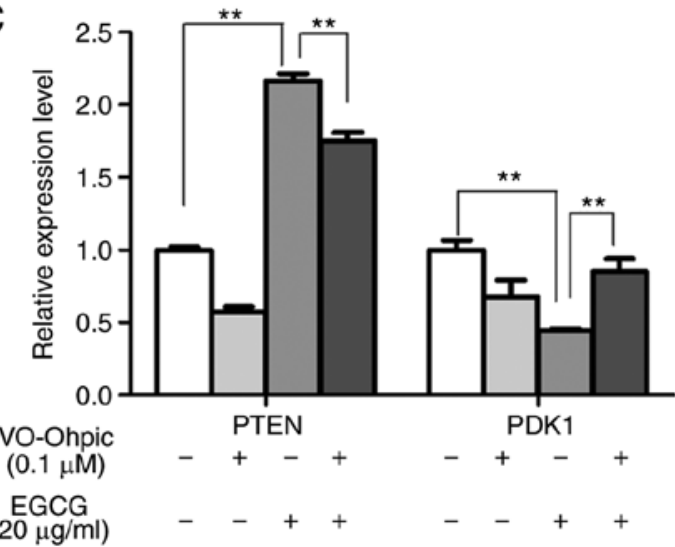

B

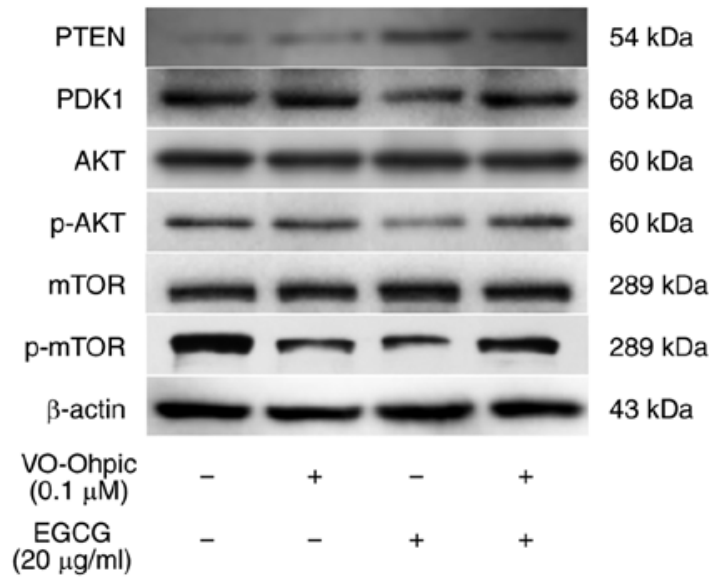

D

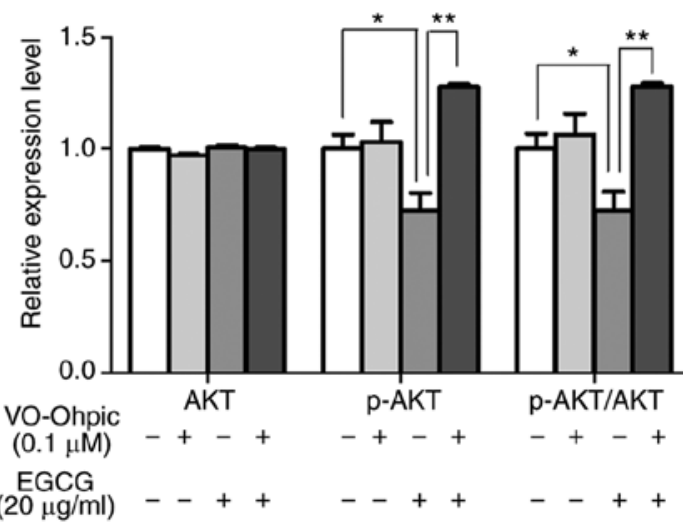

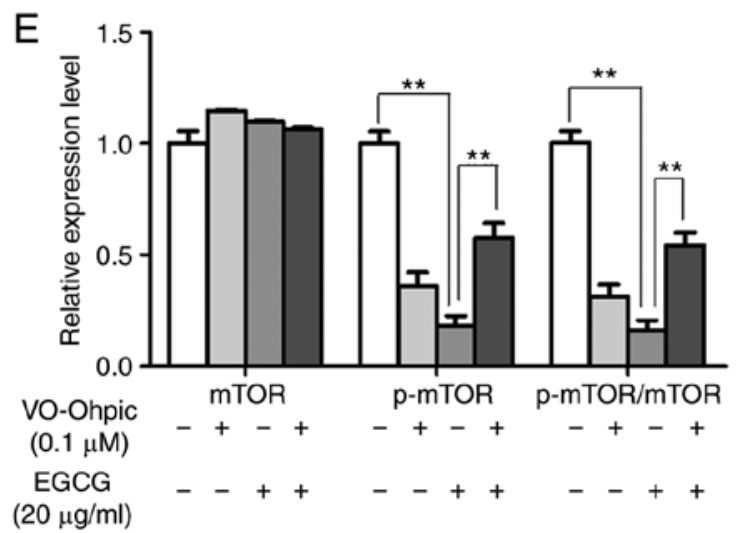

Figure 5. VO-Ohpic reverses EGCG-mediated PTEN/AKT/mTOR pathway inhibition in SKOV3 cell. (A) The mRNA expression levels of PTEN, AKT and mTOR were detected by reverse transcription-quantitative PCR. (B-E) The protein expression levels of (C) PTEN and PDK1, (D) AKT and p-AKT, and (E) mTOR and p-mTOR were analyzed by western blotting. The extent of phosphorylation of AKT and mTOR is presented as the ratio of p-AKT/AKT and p-mTOR/mTOR, respectively. $\mathrm{N}=3$. ${ }^{*} \mathrm{P}<0.05,{ }^{* *} \mathrm{P}<0.01$. EGCG, epigallocatechin-3-gallate; , phosphor.

RPE cells; the results demonstrated that $40 \mu \mathrm{g} / \mathrm{ml}$ EGCG had a small effect on the proliferation of RPE cells (Fig. S1A). In addition, to further confirm the proliferation inhibition of EGCG in SKOV3 cells, a colony formation assay was conducted. Compared with the control group, EGCG treatment significantly decreased SKOV3 cell colony formation (Fig. $1 \mathrm{G}$ and $\mathrm{H}$ ).

EGCG induces apoptosis in SKOV3 cells. The apoptotic rates of EGCG-treated cells were examined by flow cytometry. As presented in Fig. 2A and B, the apoptotic rates in the $5,10,20$ and $40 \mu \mathrm{g} / \mathrm{ml} \mathrm{EGCG} \mathrm{treatment} \mathrm{groups} \mathrm{increased} \mathrm{to}$ $6.33,9.51,17.10$ and $27.30 \%$, respectively, compared with the
$3.19 \%$ in the control group. Increasing doses of EGCG induced higher rates of SKOV3 cells apoptosis (Fig. 2B). However, the apoptotic rate of $40 \mu \mathrm{g} / \mathrm{ml}$ EGCG was only $5 \%$ in human normal RPE cells (Fig. S1B and C). The RT-qPCR results suggested that EGCG increased the mRNA expression of Bax and caspase-3, and decreased the expression of Bcl-2 compared with the control cells (Fig. 2C). Similarly, western blotting results demonstrated that EGCG treatment upregulated the protein expression of Bax and caspase- 3 and downregulated the expression of Bcl-2 in SKOV3 cells compared with the untreated control (Fig. 2D and E). Taken together, these results indicated that EGCG promoted SKOV3 cell apoptosis and regulated the expression of apoptosis-related factors. 

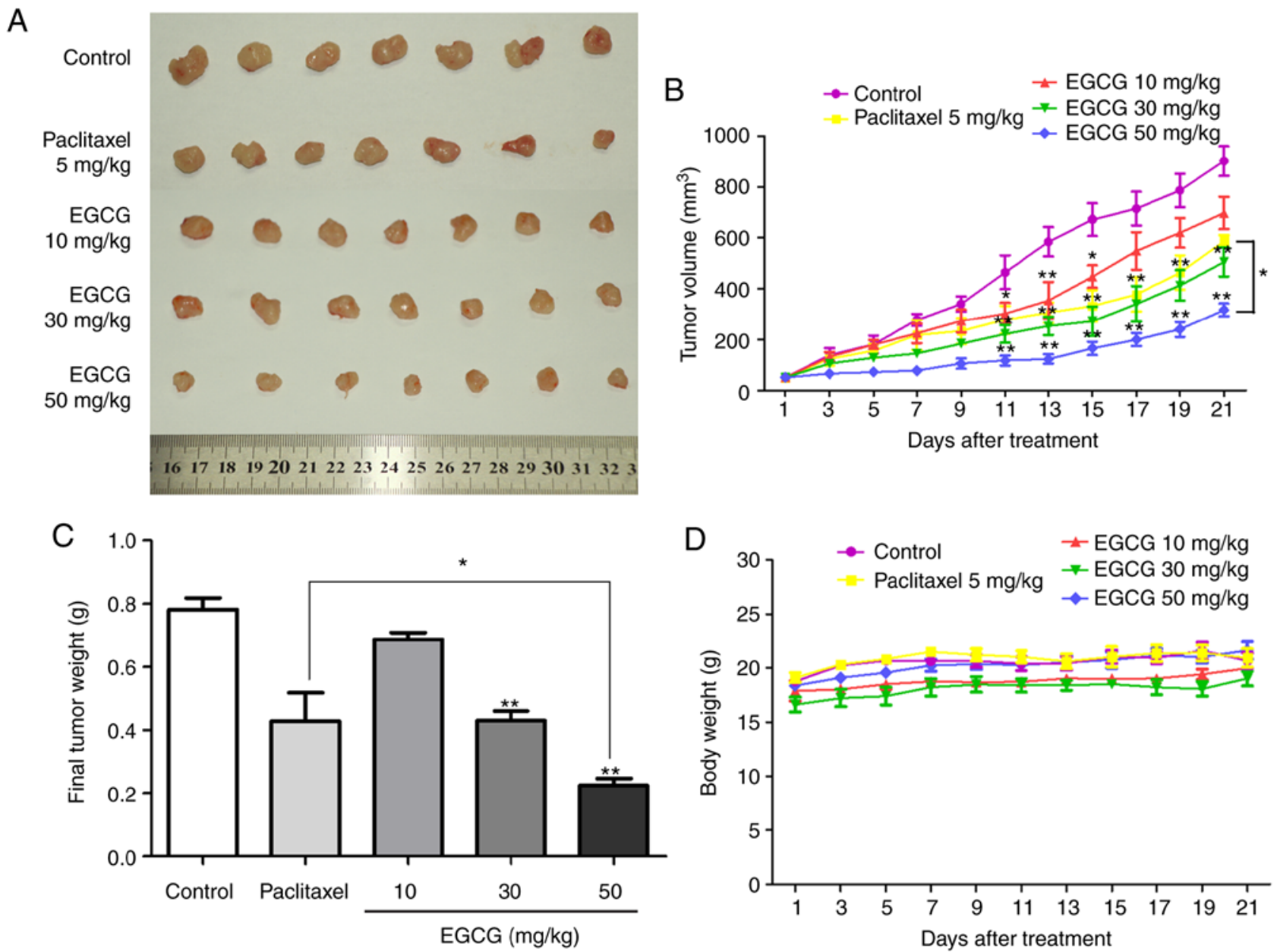

Figure 6. The antitumor effects of EGCG on ovarian cancer in nude mice bearing xenograft tumors. (A) Images of tumors in each group at the termination of the experiment. (B) Tumor volume was recorded every three days. (C) Mean tumor weights in all groups; (D) Body weight was recorded every three days. N=7 mice per group. ${ }^{*} \mathrm{P}<0.05,{ }^{* *} \mathrm{P}<0.01$ vs. control or as indicated. EGCG, epigallocatechin-3-gallate.

EGCG inhibits the activation of the PTEN/AKT/mTOR signaling pathway. The RT-qPCR and western blotting results revealed that EGCG upregulated the expression of PTEN. Thus, the expression levels of PDK1, AKT and mTOR were also determined in SKOV3 cells. The results demonstrated that EGCG reduced the mRNA levels of AKT and mTOR, and reduced the protein expression of PDK1, p-AKT and p-mTOR, whereas no changes were observed in the total AKT and mTOR protein levels (Fig. 3). Taken together, these results demonstrated that EGCG modulated the activation of the PTEN/AKT/mTOR pathway in SKOV3 cells.

VO-Ohpic trihydrate reverses the antitumor effects of EGCG. To confirm the effects of EGCG on the PTEN/AKT/mTOR pathway, VO-Ohpic was used to determine whether the effects of EGCG on SKOV3 cells were altered. First, the effect on proliferation was detected by the MTT and colony formation assays. As presented in Fig. 4A, $0.1 \mu \mathrm{M}$ VO-Ohpic alone did not affect the cell viability. The viability of cells in the EGCG and VO-Ohpic co-treatment group was higher compared with that of cells in the EGCG group, indicating that VO-Ohpic partly rescued the antiproliferative effect of EGCG in SKOV3 cells (Fig. 4B and D). Second, the flow cytometry results indicated that the apoptotic rate of control group was $1.33 \%$ and that of the VO-Ohpic group was $1.11 \%$, whereas the apoptotic rate of EGCG group was $14.00 \%$, which was significantly higher compared with that of VO-Ohpic treated group. The apoptotic rate of SKOV3 cells was 5.44\% in the EGCG and VO-Ohpic co-treatment group, which was $8.56 \%$ lower compared with the EGCG group (Fig. 4C and E). The mRNA and protein detection results demonstrated that $\mathrm{VO}-\mathrm{Ohpic}$ reversed the effects of EGCG on Bax, caspase-3 and Bcl-2 expression levels in SKOV3 cells (Fig. 4F-H). These results demonstrated that VO-Ohpic partly rescued the proapoptotic effects of EGCG. In addition, the EGCG-induced changes in the expression levels of PTEN, PDK1, AKT, p-AKT and p-mTOR were reversed by VO-Ohpic (Fig. 5). These results suggested that EGCG exerted its antiproliferative and proapoptotic effects by regulating the PTEN/AKT/mTOR signaling pathway in SKOV3 cells.

EGCG suppresses xenograft ovarian tumor growth in vivo. To investigate the antitumor effect of EGCG on ovarian cancer in vivo, a xenograft tumor model was established in BALB/c nude mice. As presented in Fig. 6A and B, EGCG significantly suppressed tumor growth in vivo. In addition, the mean tumor volume in the $50 \mathrm{mg} / \mathrm{kg}$ EGCG treatment group was lower compared with that in the $5 \mathrm{mg} / \mathrm{kg}$ paclitaxel group (Fig. 6B). Compared with normal saline treatment, 
A

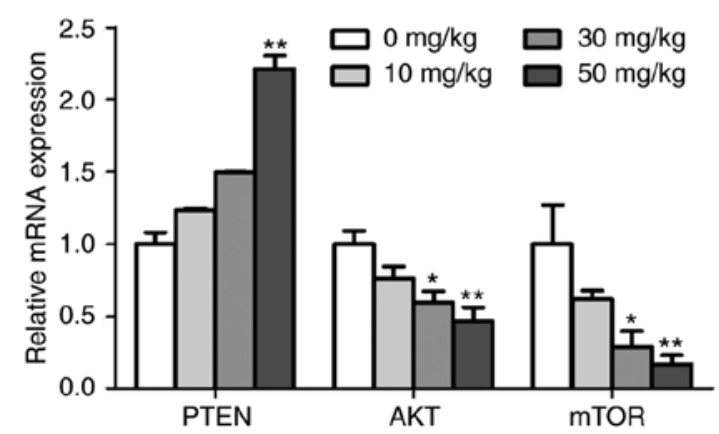

C

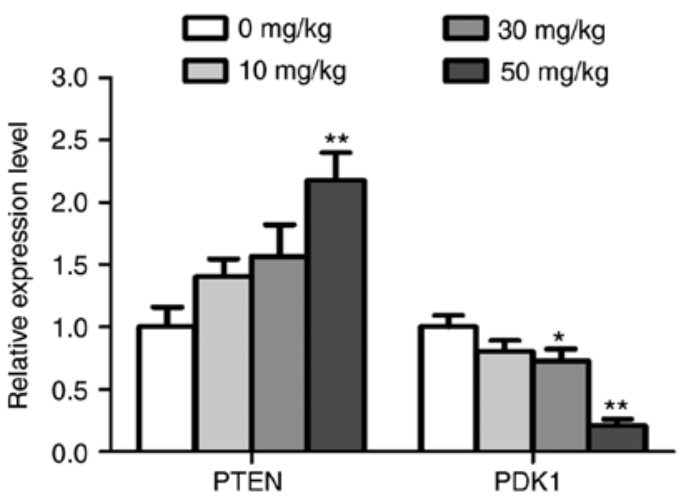

B

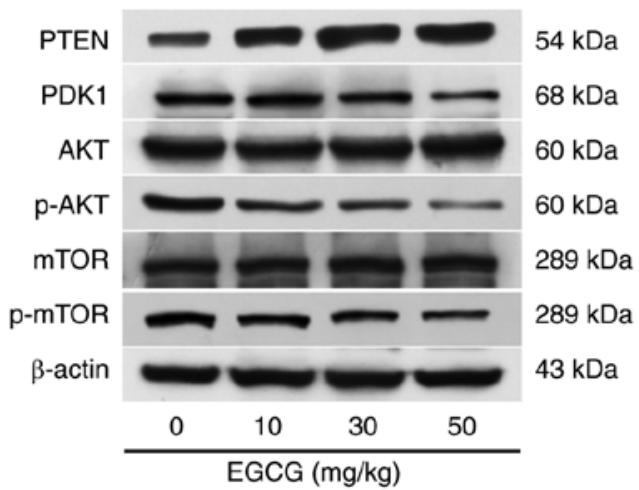

D

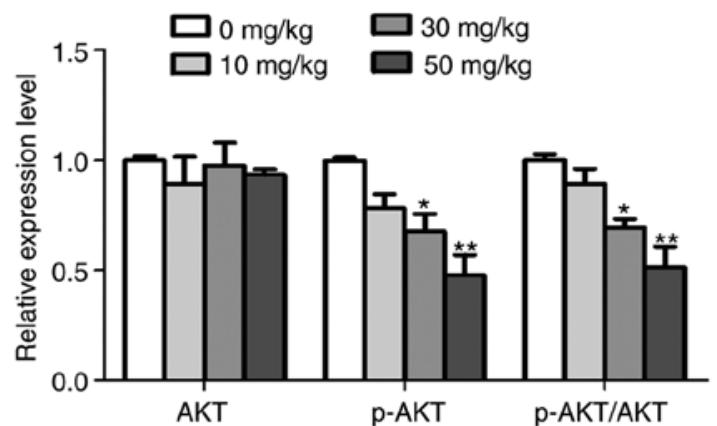

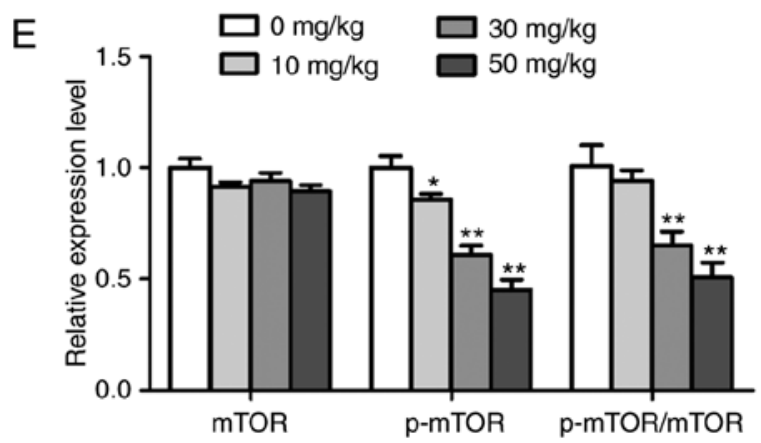

Figure 7. EGCG inhibits the PTEN/AKT/mTOR pathway activation in vivo. (A) The mRNA levers of PTEN, AKT and mTOR were analyzed by reverse transcription-quantitative PCR. (B-E) The protein expression levels of (C) PTEN and PDK1, (D) AKT and p-AKT, and (E) mTOR and p-mTOR were analyzed by western blotting in tumor tissue. The extent of phosphorylation of AKT and mTOR is presented as the ratio of p-AKT/AKT and p-mTOR/mTOR, respectively. $\mathrm{N}=3 .{ }^{*} \mathrm{P}<0.05,{ }^{* *} \mathrm{P}<0.01$ vs. control. EGCG, epigallocatechin-3-gallate; $\mathrm{p}$, phosphor.

$50 \mathrm{mg} / \mathrm{kg}$ EGCG significantly decreased the tumor weight at the end of the experiment by $71.25 \%$, whereas paclitaxel decreased it by $39.62 \%$ (Fig. 6C). In addition, EGCG-treated mice exhibited a high tolerance and did not experience significant loss of body weight (Fig. 6D). In addition, the HE staining results revealed that EGCG exerted limited effects on the mouse liver (Fig. S2), which was consistent with previous studies $(32,33)$. Furthermore, the activation of the PTEN/AKT/mTOR pathway was detected in tumor tissues. As presented in Fig. 7, mRNA and protein expression assays revealed that EGCG decreased the expression levels of AKT and mTOR, as well as increased the expression levels of PTEN in tumor tissues compared with those in the control group. These results were consistent with the in vitro assay results. Taken together, the results demonstrated that EGCG substantially suppressed tumor growth in mouse ovarian cancer xenografts, and the anticancer activity of EGCG in the xenograft tumors was partially associated with the regulation of the PTEN/AKT/mTOR pathway.

\section{Discussion}

Ovarian cancer is a common malignant gynecologic cancer, and patients typically present with advanced disease at the time of diagnosis due to a lack of early symptoms (34). In the past 10 years, therapeutic methods and drugs for ovarian cancer have been continuously developed, but the overall development is slow and the mortality of ovarian cancer is still increasing $(35,36)$. Exploring novel therapeutic drugs is essential for the treatment of ovarian cancer. EGCG has been demonstrated to possess anticancer bioactivity, which has attracted attention; EGCG has demonstrated cancer preventive activity in various types of human cancer, including lung, oral cavity and esophageal cancers $(37,38)$. Numerous studies have been conducted on the effects of EGCG on lung cancer (39-42), and it had been reported that oral administration of EGCG was feasible and safe to patients with advanced lung cancer (43). However, the present study demonstrated that EGCG exerted a stronger proliferation inhibition on ovarian cancer SKOV3 
cells compared with that on lung cancer A549 cells, although few studies $(44,45)$ have focused on the effects of EGCG on ovarian cancer. Thus, it was meaningful and worthy to study the effects of EGCG on ovarian cancer and explore the underlying molecular mechanism. In the present study, the MTT assay results revealed that EGCG inhibited SKOV3, CAOV-3 and NIH-OVCAR-3 cell proliferation; SKOV3 was the most sensitive to EGCG treatment among the four tested cell lines, and thus SKOV3 cells were selected as the research object of this study. In addition, MTT assay results revealed that $40 \mu \mathrm{g} / \mathrm{ml}$ EGCG exerted a limited effect on human retinal pigment epithelium (RPE) cell viability (Fig. S1A). In the flow cytometry analysis, the apoptotic rate of SKOV3 cells in the $40 \mu \mathrm{g} / \mathrm{ml}$ EGCG treatment group reached $27.3 \%$, whereas that in RPE cells was only 5\% (Fig. S1B and C). Additionally, EGCG increased the expression of Bax and caspase-3, and decreased the expression of Bcl-2 in SKOV3 cells compared with the untreated control group. These results indicated that EGCG exhibited anticancer effects on ovarian cancer cells, but limited cytotoxicity to normal cells.

PTEN prevents PDK1-mediated phosphorylation of AKT by converting PIP3 to PIP2, and further inhibits the phosphorylation of mTOR (46). Upregulation of PTEN suppresses cell proliferation and promotes apoptosis, which is associated with its negative regulation of the AKT/mTOR pathway (47). Abnormal activation of the AKT/mTOR pathway has been observed in various types of cancer, including ovarian cancer (48-51). Certain molecules targeting this pathway, including AKT inhibitor MK-2206 (52), mTOR inhibitor AZD8055 (53) and dual $\mathrm{PI} 3 \mathrm{~K} / \mathrm{mTOR}$ inhibitor PF-04691502 (54), have been used for cancer treatment. Multiple studies have demonstrated that the AKT/mTOR pathway serves a prominent role in ovarian cancer tumorigenesis, proliferation and progression (55-57). In the bioinformatics analysis performed by Shen et al (58), AKT was also identified as a target protein in ovarian cancer, but it was not verified if EGCG exerted anti-ovarian cancer effect by targeting AKT. Therefore, the present study evaluated the expression of PTEN, PDK1, AKT and mTOR in ovarian cancer cells after EGCG treatment. The results suggested that the PTEN/AKT/mTOR pathway was involved in anti-ovarian cancer activity of EGCG. In addition, the PTEN inhibitor VO-Ohpic reversed the effects of EGCG on the proliferation inhibition, apoptosis induction and the PTEN/AKT/mTOR pathway activation in ovarian cancer cells. These results demonstrated that EGCG exerted anticancer effects in SKOV3 cells through the PTEN/AKT/mTOR pathway.

To further confirm the role of EGCG in the proliferation inhibition of ovarian cancer, an in vivo experiment was performed in the present study, which demonstrated that EGCG significantly decreased tumor growth in nude mice compared with the control group, and the mean tumor volume in the $50 \mathrm{mg} / \mathrm{kg}$ EGCG group was markedly attenuated compared with those in the control and $5 \mathrm{mg} / \mathrm{kg}$ paclitaxel groups. EGCG-treated mice exhibited high tolerance and did not experience significant loss of body weight.

Paclitaxel is the first-line drug for ovarian cancer treatment; standard initial therapy for ovarian cancer is platinum/paclitaxel combination chemotherapy (59). The in vivo results of the present study demonstrated that $50 \mathrm{mg} / \mathrm{kg}$ EGCG treatment exhibited stronger growth suppression on ovarian cancer cells compared with $5 \mathrm{mg} / \mathrm{kg}$ paclitaxel, indicating that EGCG may be a potential therapeutic agent for ovarian cancer. In addition, EGCG treatment resulted in an inhibition of the PTEN/AKT/mTOR pathway in nude mice. These results suggested that EGCG exerted anti-ovarian cancer effects in vivo via the $\mathrm{PTEN} / \mathrm{AKT} / \mathrm{mTOR}$ pathway.

In summary, the results of the present study suggested that EGCG exerted stronger proliferation inhibition on SKOV3 cells compared with A549 cells, and the PTEN/AKT/mTOR signaling pathway was involved in the anti-ovarian cancer effects of EGCG in vitro and in vivo. However, future analysis of PTEN or AKT overexpression and blood test (detection of liver- or heart-related enzymes ALT, AST and CK) after EGCG treatment in nude mice will be required to support the potential application of EGCG in ovarian cancer therapy.

\section{Acknowledgements}

Not applicable.

\section{Funding}

This study was supported by the National Natural Science Foundation of China (grant nos. 31460229, 81760443 and 81760663), the Guangxi Natural Science Foundation (grant no. 2017GXNSFDA198029), the Small Talent Highland Fund in Guangxi (grant no. 201707) and The Scientific Research and Technology Development Plan of Guilin (grant no. 20170109-38).

\section{Availability of data and materials}

The datasets used and/or analyzed during the current study are available from the corresponding author on reasonable request.

\section{Authors' contributions}

XC, JW, MLF and JLQ designed the study. JLQ, MLF, MJH and DY performed the experiments. JLQ and JW wrote the manuscript. HWL, XML and XG reviewed and revised the manuscript. FXH and HPL conducted data analysis. All authors read and approved the final manuscript.

\section{Ethics approval and consent to participate}

Ethical approval for the use of animals was obtained prior to the start of this study from the Institutional Animal Care and Use Committee of Guilin Medical University (Guilin, China).

\section{Patient consent for publication}

Not applicable.

\section{Competing interests}

The authors declare that they have no competing interests. 


\section{References}

1. Khan $\mathrm{N}$ and Mukhtar $\mathrm{H}$ : Tea polyphenols in promotion of human health. Nutrients 11: pii: E39, 2018.

2. Wang YQ, Lu JL, Liang YR and Li QS: Suppressive effects of EGCG on cervical cancer. Molecules 23: pii: E2334, 2018.

3. Wang LX, Shi YL, Zhang LJ, Wang KR, Xiang LP, Cai ZY, Lu JL, Ye JH, Liang YR and Zheng XQ: Inhibitory effects of (-)-Epigallocatechin-3-gallate on esophageal cancer. Molecules 24: pii: E954, 2019.

4. Sanna V, Singh CK, Jashari R, Adhami VM, Chamcheu JC, Rady I, Sechi M, Mukhtar H and Siddiqui IA: Targeted nanoparticles encapsulating (-)-epigallocatechin-3-gallate for prostate cancer prevention and therapy. Sci Rep 7: 41573, 2017.

5. Hong OY, Noh EM, Jang HY, Lee YR, Lee BK, Jung SH, Kim JS and Youn HJ: Epigallocatechin gallate inhibits the growth of MDA-MB-231 breast cancer cells via inactivation of the beta-catenin signaling pathway. Oncol Lett 14: 441-446, 2017.

6. Flores-Perez A, Marchat LA, Sánchez LL, Romero-Zamora D, Arechaga-Ocampo E, Ramírez-Torres N, Chávez JD Carlos-Reyes Á, Astudillo-de la Vega H, Ruiz-García E, et al Differential proteomic analysis reveals that EGCG inhibits HDGF and activates apoptosis to increase the sensitivity of non-small cells lung cancer to chemotherapy. Proteomics Clin Appl 10: 172-182, 2016.

7. Ying L, Yan F, Williams BR, Xu P, Li X, Zhao Y, Hu Y, Wang Y, $\mathrm{Xu}$ D and Dai J: (-)-Epigallocatechin-3-gallate and EZH2 inhibitor GSK343 have similar inhibitory effects and mechanisms of action on colorectal cancer cells. Clin Exp Pharmacol Physiol 45: 58-67, 2018

8. Dhatwalia SK, Kumar M and Dhawan DK: Role of EGCG in containing the progression of lung tumorigenesis-a multistage targeting approach. Nutr Cancer 70: 334-349, 2018.

9. Shi J, Liu F, Zhang W, Liu X, Lin B and Tang $X$ Epigallocatechin-3-gallate inhibits nicotine-induced migration and invasion by the suppression of angiogenesis and epithelial-mesenchymal transition in non-small cell lung cancer cells. Oncol Rep 33: 2972-2980, 2015.

10. Chen Y, Wang XQ, Zhang Q, Zhu JY, Li Y, Xie CF, Li XT, Wu JS, Geng SS, Zhong CY and Han HY: (-)-Epigallocatechin-3-Gallate inhibits colorectal cancer stem cells by suppressing Wnt/ $\beta$-catenin pathway. Nutrients 9: pii: E572, 2017.

11. Liu C, Li P, Qu Z, Xiong W, Liu A and Zhang S: Advances in the antagonism of Epigallocatechin-3-gallate in the treatment of digestive tract tumors. Molecules 24: pii: E1726, 2019.

12. Rawangkan A, Wongsirisin P, Namiki K, Iida K, Kobayashi Y, Shimizu Y, Fujiki H and Suganuma M: Green tea catechin is an alternative immune checkpoint inhibitor that inhibits PD-L1 expression and lung tumor growth. Molecules 23: pii: E2071, 2018

13. Ma YC, Li C, Gao F, Xu Y, Jiang ZB, Liu JX and Jin LY: Epigallocatechin gallate inhibits the growth of human lung cancer by directly targeting the EGFR signaling pathway. Oncol Rep 31: 1343-1349, 2014

14. Wang J, Sun P, Wang Q, Zhang P, Wang Y, Zi C, Wang X and Sheng J: (-)-Epigallocatechin-3-gallate derivatives combined with cisplatin exhibit synergistic inhibitory effects on non-small-cell lung cancer cells. Cancer Cell Int 19: 266, 2019.

15. Meng J, Chang C, Chen Y, Bi F, Ji C and Liu W: EGCG overcomes gefitinib resistance by inhibiting autophagy and augmenting cell death through targeting ERK phosphorylation in NSCLC. Onco Targets Ther 12: 6033-6043, 2019.

16. Deng P, Hu C, Xiong Z, Li Y, Jiang J, Yang H, Tang Y, Cao L and Lu R: Epigallocatechin-3-gallate-induced vascular normalization in A549-cell xenograft-bearing nude mice: Therapeutic efficacy in combination with chemotherapy. Cancer Manag Res 11: 2425-2439, 2019.

17. Yan C, Yang J, Shen L and Chen X: Inhibitory effect of Epigallocatechin gallate on ovarian cancer cell proliferation associated with aquaporin 5 expression. Arch Gynecol Obstet 285 459-467, 2012.

18. Wang F, Chang Z, Fan Q and Wang L: Epigallocatechin-3-gallate inhibits the proliferation and migration of human ovarian carcinoma cells by modulating p38 kinase and matrix metalloproteinase-2. Mol Med Rep 9: 1085-1089, 2014.

19. Padmakumar S, Parayath NN, Nair SV, Menon D and Amiji MM: Enhanced anti-tumor efficacy and safety with metronomic intraperitoneal chemotherapy for metastatic ovarian cancer using biodegradable nanotextile implants. J Control Release 305: 29-40, 2019.
20. Mahalaxmi I, Devi SM, Kaavya J, Arul N, Balachandar V and Santhy KS: New insight into NANOG: A novel therapeutic target for ovarian cancer (OC). Eur J Pharmacol 852: 51-57, 2019.

21. Pisanic TR II, Cope LM, Lin SF, Yen TT, Athamanolap P, Asaka R, Nakayama K, Fader AN, Wang TH, Shih IM and Wang TL: Methylomic analysis of ovarian cancers identifies tumor-specific alterations readily detectable in early precursor lesions. Clin Cancer Res 24: 6536-6547, 2018.

22. Chuffa LGD, Reiter RJ and Lupi LA: Melatonin as a promising agent to treat ovarian cancer: Molecular mechanisms. Carcinogenesis 38: 945-952, 2017.

23. Madariaga A, Lheureux S and Oza A: Tailoring ovarian cancer treatment: Implications of BRCA1/2 mutations. Cancers 11: pii: E416, 2019 .

24. Roane BM, Arend RC and Birrer MJ: Review: Targeting the transforming growth Factor-beta pathway in ovarian cancer. Cancers (Basel) 11: pii: E668, 2019.

25. Tomao F, Marchetti C, Romito A, Di Pinto A, Di Donato V, Capri O, Palaia I, Monti M, Muzii L and Benedetti Panici P Overcoming platinum resistance in ovarian cancer treatment: From clinical practice to emerging chemical therapies. Expert Opin Pharmacother 18: 1443-1455, 2017.

26. Zhang X, Feng Y, Wang XY, Zhang YN, Yuan CN, Zhang SF, Shen YM, Fu YF, Zhou CY, Li X, et al: The inhibition of UBC13 expression and blockage of the DNMT1-CHFR-Aurora A pathway contribute to paclitaxel resistance in ovarian cancer. Cell Death Dis 9: 93, 2018.

27. Yap TA, Carden CP and Kaye SB: Beyond chemotherapy: Targeted therapies in ovarian cancer. Nat Rev Cancer 9: 167-181, 2009.

28. Gasparri M, Bardhi E, Ruscito I, Papadia A, Farooqi AA, Marchetti C, Bogani G, Ceccacci I, Mueller MD and Benedetti Panici P: PI3K/AKT/mTOR pathway in ovarian cancer treatment: Are we on the right track? Geburtshilfe Frauenheilkd 77: 1095-1103, 2017.

29. Mabuchi S, Kuroda H, Takahashi R and Sasano T: The PI3K/AKT/mTOR pathway as a therapeutic target in ovarian cancer. Gynecol Oncol 137: 173-179, 2015.

30. Xinqiang S, Mu Z, Lei $\mathrm{C}$ and Mun LY: Bioinformatics analysis on molecular mechanism of green tea compound Epigallocatechin-3-gallate against ovarian cancer. Clin Transl Sci 10: 302-307, 2017.

31. Livak KJ and Schmittgen TD: Analysis of relative gene expression data using real-time quantitative PCR and the 2(-Delta Delta C(T)) method. Methods 25: 402-408, 2001

32. Luo KW, Wei C, Lung WY, Wei XY, Cheng BH, Cai ZM and Huang WR: EGCG inhibited bladder cancer SW780 cell proliferation and migration both in vitro and in vivo via down-regulation of NF- $\kappa$ B and MMP-9. J Nutr Biochem 41: 56-64, 2017.

33. Pan H, Chen J, Shen K, Wang X, Wang P, Fu G, Meng H, Wang Y and Jin B: Mitochondrial modulation by Epigallocatechin 3-Gallate ameliorates cisplatin induced renal injury through decreasing oxidative/nitrative stress, inflammation and NF-kB in mice. PLoS One 10: e0124775, 2015.

34. Wang L, Yang R, Zhao L, Zhang X, Xu T and Cui M: Basing on uPAR-binding fragment to design chimeric antigen receptors triggers antitumor efficacy against uPAR expressing ovarian cancer cells. Biomed Pharmacother 117: 109173, 2019.

35. Russell MR, Graham C, D'Amato A, Gentry-Maharaj A, Ryan A, Kalsi JK, Whetton AD, Menon U, Jacobs I and Graham RLJ: Diagnosis of epithelial ovarian cancer using a combined protein biomarker panel. Br J Cancer 121: 483-489, 2019.

36. Yarmolinsky J, Relton CL, Lophatananon A, Muir K, Menon U, Gentry-Maharaj A, Walther A, Zheng J, Fasching P, Zheng W, et al: Appraising the role of previously reported risk factors in epithelial ovarian cancer risk: A Mendelian randomization analysis. PLoS Med 16: e1002893, 2019.

37. Yang CS and Hong J: Prevention of chronic diseases by tea: Possible mechanisms and human relevance. Annu Rev Nutr 33: 161-181, 2013

38. Zhang L, He Y, Wu X, Zhao G, Zhang K, Yang CS, Reiter RJ and Zhang J: Melatonin and (-)-Epigallocatechin-3-Gallate: Partners in fighting cancer. Cells 8: pii: E745, 2019.

39. Zhang L, Xie J, Gan R, Wu Z, Luo H, Chen X, Lu Y, Wu L and Zheng D: Synergistic inhibition of lung cancer cells by EGCG and NF- $\kappa$ B inhibitor BAY11-7082. J Cancer 10: 6543-6556, 2019.

40. Bhardwaj V and Mandal AKA: Next-Generation sequencing reveals the role of Epigallocatechin-3-gallate in regulating putative novel and known microRNAs which target the MAPK pathway in non-small-cell lung cancer A549 cells. Molecules 24: pii: E368, 2019. 
41. Yu C, Jiao Y, Xue J, Zhang Q, Yang H, Xing L, Chen G, Wu J, Zhang S, Zhu W and Cao J: Metformin sensitizes non-small cell lung cancer cells to an Epigallocatechin-3-Gallate (EGCG) treatment by suppressing the Nrf2/HO-1 signaling pathway. Int J Biol Sci 13: 1560-1569, 2017.

42. Li M, Li JJ, Gu QH, An J, Cao LM, Yang HP and Hu CP: EGCG induces lung cancer A549 cell apoptosis by regulating $\mathrm{Ku} 70$ acetylation. Oncol Rep 35: 2339-2347, 2016.

43. Zhao H, Zhu W, Xie P, Li H, Zhang X, Sun X, Yu J and Xing L: A phase I study of concurrent chemotherapy and thoracic radiotherapy with oral epigallocatechin-3-gallate protection in patients with locally advanced stage III non-small-cell lung cancer. Radiother Oncol 110: 132-136, 2014.

44. Tian M, Tian D, Qiao X, Li J and Zhang L: Modulation of Myb-induced NF-kB-STAT3 signaling and resulting cisplatin resistance in ovarian cancer by dietary factors. J Cell Physiol 234 21126-21134, 2019.

45. Chen H, Landen CN, Li Y, Alvarez RD and Tollefsbol TO Epigallocatechin gallate and sulforaphane combination treatment induce apoptosis in paclitaxel-resistant ovarian cancer cells through hTERT and Bcl-2 down-regulation. Exp Cell Res 319: 697-706, 2013.

46. Pérez-Ramírez C, Cañadas-Garre M, Molina MÁ,Faus-Dáder MJ and Calleja-Hernández MÁ: PTEN and PI3K/AKT in non-small-cell lung cancer. Pharmacogenomics 16: 1843-1862, 2015.

47. Chen Q, Weng HY, Tang XP, Lin Y, Yuan Y, Li Q, Tang Z, Wu HB, Yang S, Li Y, et al: ARL4C stabilized by AKT/mTOR pathway promotes the invasion of PTEN-deficient primary human glioblastoma. J Pathol 247: 266-278, 2019.

48. Xu JL, Wang ZW, Hu LM, Yin ZQ, Huang MD, Hu ZB, Shen HB and Shu YQ: Genetic variants in the PI3K/PTEN/AKT/mTOR pathway predict Platinum-based chemotherapy response of advanced non-small cell lung cancers in a Chinese population. Asian Pac J Cancer Prev 13: 2157-2162, 2012.

49. Lin YT, Wang HC, Hsu YC, Cho CL, Yang MY and Chien CY: Capsaicin induces autophagy and apoptosis in human nasopharyngeal carcinoma cells by downregulating the $\mathrm{PI} 3 \mathrm{~K} / \mathrm{AKT} / \mathrm{mTOR}$ pathway. Int J Mol Sci 18: pii: E1343, 2017.

50. Chen J, Zhao KN, Li R, Shao R and Chen C: Activation of $\mathrm{PI} 3 \mathrm{~K} / \mathrm{Akt} / \mathrm{mTOR}$ pathway and dual inhibitors of PI3K and mTOR in endometrial cancer. Curr Med Chem 21: 3070-3080, 2014.

51. Liu HY, Zhang YY, Zhu BL, Feng FZ, Yan H, Zhang HY and Zhou B: miR-21 regulates the proliferation and apoptosis of ovarian cancer cells through PTEN/PI3K/AKT. Eur Rev Med Pharmacol Sci 23: 4149-4155, 2019.
52. Yap TA, Yan L, Patnaik A, Tunariu N, Biondo A, Fearen I, Papadopoulos KP, Olmos D, Baird R, Delgado L, et al: Interrogating two schedules of the AKT inhibitor MK-2206 in patients with advanced solid tumors incorporating novel pharmacodynamic and functional imaging biomarkers. Clin Cancer Res 20: 5672-5685, 2014.

53. Pétigny-Lechartier C, Duboc $\mathrm{C}$ and Jebahi A: The mTORC1/2 inhibitor AZD8055 strengthens the efficiency of the MEK inhibitor trametinib to reduce the Mcl-1/[Bim and Puma] ratio and to Sensitize Ovarian Carcinoma cells to ABT-737. Mol Cancer Ther 16: 102-115, 2017.

54. Wainberg ZA, Alsina M, Soares HP, Braña I, Britten CD, Del Conte G, Ezeh P, Houk B, Kern KA, Leong S, et al: A Multi-Arm phase I study of the PI3K/mTOR inhibitors PF-04691502 and Gedatolisib (PF-05212384) plus Irinotecan or the MEK inhibitor PD-0325901 in advanced cancer. Target Oncol 12: 775-785, 2017.

55. Biswas R, Ahn JC and Kim JS: Sulforaphene synergistically sensitizes cisplatin via enhanced mitochondrial dysfunction and PI3K/PTEN modulation in ovarian cancer cells. Anticancer Res 35: 3901-3908, 2015.

56. Cai J, Xu L, Tang H, Yang Q, Yi X, Fang Y, Zhu Y and Wang Z: The role of the PTEN/PI3K/Akt pathwayon prognosis in epithelial ovarian cancer: A meta-analysis. Oncologist 19: 528-535, 2014.

57. Ediriweera MK, Tennekoon KH and Samarakoon SR: Role of the PI3K/AKT/mTOR signaling pathway in ovarian cancer: Biological and therapeutic significance. Semin Cancer Biol 59: 147-160, 2019.

58. Shen J, Yu S, Sun X, Yin M, Fei J and Zhou J: Identification of key biomarkers associated with development and prognosis in patients with ovarian carcinoma: Evidence from bioinformatic analysis. J Ovarian Res 12: 110, 2019.

59. Steffensen KD, Smoter M, Waldstrøm M, Grala B, Bodnar L, Stec R, Szczylik C and Jakobsen A: Resistance to first line platinum paclitaxel chemotherapy in serous epithelial ovarian cancer: The prediction value of ERCC1 and Tau expression. Int J Oncol 44: 1736-1744, 2014.

This work is licensed under a Creative Commons Attribution-NonCommercial-NoDerivatives 4.0 International (CC BY-NC-ND 4.0) License. 